\title{
Stigma Experienced By Primary Care Givers of Persons with Epilepsy and Mental Illness : A Comparative Study
}

\author{
Kamlesh Kumar Sahu ${ }^{1}$, Arvind Kumar ${ }^{2}$, Sudeshna Basu Mukherjee ${ }^{3}$, Soma Sahu ${ }^{4}$, A. N. Verma ${ }^{5}$ \\ ${ }^{1}$ (*corresponding author) Ph.D. Scholar, Department of Sociology \\ University of Calcutta, India \& Assistant Professor, Department of Psychiatric Social Work, Institute of Psychiatry \\ (IPGME\&R, SSKM Hospital) Email : withkamlesh@gmail.com \\ ${ }^{2}$ Psychiatric Social Worker (PSW), Department of Psychiatric Social Work, Ranchi Institute of Neuro Psychiatry and \\ Allied Sciences (RINPAS) Kanke, Ranchi \\ ${ }^{3}$ Associate Professor \& Head, Department of Sociology, University of Calcutta \\ ${ }^{4}$ Lecturer, Department of Psychology, Bangabasi College, Kolkata \\ ${ }^{5}$ Associate Professor (Former), Department of Psychiatric Social Work, RINPAS, Kanke, Ranchi
}

\section{ABSTRACT}

Stigma is society's negative evaluation of particular features or behaviour. Various medical conditions are stigmatized. The goals of the study were to assess and compare the stigma experienced by Primary Care Givers (PCG) of persons with epilepsy and mental illness and to find out the relationship between stigma and attribution. The study was a cross sectional hospital based study used purposive sampling techniques and sampled 100 caregivers of each group; persons with mental illness and persons with epilepsy from the outpatient department (OPD) of Central Institute of Psychiatry (CIP), Ranchi, India. Family Interview Schedule to assess stigma and causal attribution was used. Result reveals that the primary caregivers of persons with mental illness experienced a greater degree of stigma than the primary caregivers of epilepsy. Difference in causal attribution of these two illnesses by the PCG may have important implication in psycho-educational programs of intervention to dispel stigma.

Key words : Stigma, epilepsy, mental illness, attitude, discrimination

\section{INTRODUCTION}

Social stigma is the severe disapproval of or discontent with a person on the grounds of characteristics that distinguish them from other members of a society. Stigma is the situation of the individual who is disqualified from full social acceptance (Goffiman, 1963). In a broader term "stigma is a social process or related personal experience characterized by exclusion, rejection, blame or devaluation that results from an adverse social judgment about a person or group" (Weiss \& Ramakrishna, 1996). Varied dimensions of stigmatized medical conditions e.g. leprosy (Opala \& Boillot, 1996), cancer (Fife \& Wright, 2000), mental illness (Angermeyer \& Matschinger, 1994, Corrigan \& Penn, 1999, Phelan et al., 2000) and epilepsy (Pasternak, 1992, Sahu et al., 2009) include the nature of an illness, its history, and attributed characteristics; sources of the creation and perpetuation of stigma; the nature of the populations who perceived to carry the illness; the kinds of treatments and practitioners sought for the condition; and how individuals with stigmatized medical conditions cope with societal 


\section{Stigma Experienced by Primary Care Givers : A Comparative Study}

insults that endanger their personal identity, social life, and economic opportunities (Ablon, 2002). These different stigmatized conditions are also associated with specific features of stigma, which may be locally rationalized with reference to conditionspecific ideas about those conditions, their social implications, and why they are considered socially unacceptable. Exaggerated concerns about the risk of contagion may promote the stigma of some infectious diseases, such as HIV / AIDS and Tuberculosis (TB). Physical deformities (e.g., edematous limbs or scrotum with lymphatic filariasis); unacceptable scratching with onchodermatitis; exaggerated concerns about dangerousness with schizophrenia/ mental illness; or moral condemnation that blames people with leprosy, epilepsy or HIV infection may all be distinctive features of condition-specific stigma. It appears to be closely associated with the experience, meaning, and behaviour associated with the disease among affected persons and unaffected persons in the community who have either no idea or very blurred ideas about it (Weiss et al. 2001).

Epilepsy is a chronic brain disorder characterized by transient, episodic, excessive discharge of cerebral neurons which may be associated with convulsive movements or disturbances in feeling, behaviour or both. In other words, epilepsy is an altered physiologic state with a rhythmical and repetitive hyper synchronous discharge which can be observed on the electroencephalogram (Pandey, 2001). Epilepsy affects 20 to 40 million people worldwide (Mario, 2000). In India the prevalence rate stands at around 5/1000 population, at this rate present estimate of total persons with epilepsy in this country is about 5 million and incidence rate varies from 38 to 49.3 per 100,000 population (Ray et al., 2002).

Mental illnesses refer to disorders generally characterized by dysregulation of mood, thought, and/or behavior, as recognized by the Diagnostic and Statistical Manual, 4th edition (DSM-IV), of the American Psychiatric Association (2000). A mental illness can also be defined as a health condition that changes a person's thinking, feelings, or behavior (or all three) and that causes the person distress and difficulty in functioning. The mental and behavioral disorders account for about $12 \%$ of the global burden of diseases (WHO, 2001). Depression, alcohol use disorders, schizophrenia and bipolar disorders constitute the top 10 conditions contributing to the global burden of disease among the age group of 15-44 years. Mental and behavioral disorders are present, in about $10 \%$ of the adult population, at any given point of time (Demyttenaere et al., 2004). A meta analysis of available Indian studies carried out by Reddy and Chandrasekhar (1998) revealed the overall prevalence of mental disorders as 5.8\% among the population in India. A review analysis of 15 epidemiological studies by Ganguli (2000) on the prevalence of mental disorders in India estimated the national prevalence of all mental disorders as 70.5 per 1000 in the rural and 73 per 1000 in the urban population.

Stigmatization not only affects those who possess a stigmatized condition, it also impacts others. Research has shown people associated with stigmatized individuals (e.g., family, friends, caregivers) are routinely devalued purely as a result of their connection with someone with a stigmatized condition (Hebl \& Mannix, 2003; Neuberg, et al, 1994). Stigma is a topic that began to interest social scientists a mere five decades ago. More recently it has become an important topic for health social sciences concerned with the burden of illness and the social determinants of disease control. Stigma may contribute to suffering, delay help seeking, and encourage non-adherence to treatment of people with stigmatized conditions. Its social impact may also disrupt families and lessen support for services, community programmes, and research. Number of studies revealed that stigma is attached with mental illness and epilepsy, studies also focus various dimensions or aspects of stigma related to these two illnesses but very few studies compare it. Comparative study may give an insight on varied dimensions of stigmatized mental illness and epilepsy. 


\section{Stigma Experienced by Primary Care Givers : A Comparative Study}

\section{OBJECTIVES}

The present study was intended to assess and compare the presence and degree of stigma experienced by primary care givers (PCG) of persons with mental illness and epilepsy, to find out the causal attribution for mental illness and epilepsy among the PCG.

\section{METHOD AND MATERIALS}

It was a cross sectional hospital based study. It sampled equal number of two outpatient groups purposively, 100 persons with a mental illness (with psychotic symptoms, since this is considered to found only in major and severe mental illnesses) diagnosed according to International Classification of Mental and Behavioral Disorders (ICD-10) version 10 (ICD-10; WHO, 1992) and 100 persons with epilepsy according to International League Against Epilepsy (ILAE, 1981) with either sex, between 18 to 65 years of age and attending OPD of Central Institute of Psychiatry, Kanke, Ranchi, India were taken for the study. Persons with mental illness or epilepsy having any co-morbid diagnosis or presented with pseudo seizures or with any chronic physical illness were excluded. Primary care givers living with the persons with mental illness or epilepsy in same house hold for at least one year and spend maximum time and effort in caring for their ward with either sex between 18-65 years and who had given consent were interviewed. Primary care givers with chronic physical illness, substance dependence, having any other family member with a psychiatric or neurological or chronic physical illness or scoring more than 1 on General Health Questionnaire - 5 (GHQ-5) (Shamsundar et al, 1986) were excluded.

Relevant demographic and clinical data was then obtained. Hindiversion of Family Interview Schedule (FIS) to assess both stigma and causal attribution were then administered with primary care givers. Tool had been translated, modified and standardized in earlier works (Sahu, et al., 2009; Suman, 2003;) especially to make it relevant in epilepsy group. FIS used in the International Study of Schizophrenia by WHO (Sartarius et al., 1996) also adopted for study 'How Stigmatizing Schizophrenia in India' by Thara and Srinivasan, (2000). In the current study for the assessment of stigma, the Stigma Section of FIS was used. The stigma assessment section comprised of 14 questions on various items like - difficulties with neighbours, marriage, and fear of the fact of mental illness being revealed to others, feeling of shame, embarrassment, guilt \& depression. The degree of stigma on each of the items is scored on a four point scale (0-3) ranging from 'not at all' to 'is a lot'. The total stigma score was compiled by adding the score on the 14 items of the questionnaire. For the assessment of attribution/causes for the illness attribution items of attribution section were taken from the above mentioned FIS. This 24 attribute items, was scored on 5 point scale (1-5), ranging from 'very unlikely' to 'very likely'.

\section{RESULT AND DISCUSSION}

\section{SOCIO-DEMOGRAPHIC AND CLINICAL PROFILE}

Table 1. Socio-demographic and Clinical Profile of the Persons with Epilepsy and Mental illness

\begin{tabular}{|c|c|c|c|c|c|}
\hline Variables & $\begin{array}{c}\text { Epilepsy } \\
\text { Mean } \pm \text { SD/n } \\
N=100\end{array}$ & $\begin{array}{l}\text { Mental illness } \\
\text { Mean } \pm \text { SD/n } \\
\mathbf{N}=100\end{array}$ & & df & $\mathbf{p}$ \\
\hline Age (in years) & $19.89 \pm 10.66$ & $3 w 4.66 \pm 11.87$ & -9.225 & 198 & $000^{* * *}$ \\
\hline \multicolumn{6}{|l|}{ Sex } \\
\hline $\begin{array}{l}\text { Male } \\
\text { Female }\end{array}$ & $\begin{array}{l}60 \\
40\end{array}$ & $\begin{array}{l}59 \\
41\end{array}$ & .021 & 1 & .885 \\
\hline
\end{tabular}


Stigma Experienced by Primary Care Givers : A Comparative Study

\begin{tabular}{|c|c|c|c|c|c|}
\hline Variables & $\begin{array}{c}\text { Epilepsy } \\
\text { Mean } \pm \text { SD/n } \\
\mathbf{N}=100\end{array}$ & $\begin{array}{l}\text { Mental illness } \\
\text { Mean } \pm \text { SD/n } \\
\mathbf{N}=100\end{array}$ & & df & $\mathbf{p}$ \\
\hline Education (in yrs.) & $6.40 \pm 4.64$ & $8.80 \pm 4.53$ & -3.702 & 198 & $000^{* * *}$ \\
\hline $\begin{array}{c}\text { Religion } \\
\text { Hindu } \\
\text { Others }\end{array}$ & $\begin{array}{l}64 \\
36\end{array}$ & $\begin{array}{c}93 \\
3\end{array}$ & 34.687 & 1 & $.000^{* * *}$ \\
\hline $\begin{array}{l}\text { Category } \\
\text { General } \\
\text { Reserved }\end{array}$ & $\begin{array}{l}31 \\
69\end{array}$ & $\begin{array}{l}33 \\
67\end{array}$ & .092 & 1 & .762 \\
\hline $\begin{array}{l}\text { Marital Status } \\
\text { Unmarried } \\
\text { Married }\end{array}$ & $\begin{array}{l}79 \\
21\end{array}$ & $\begin{array}{l}36 \\
64\end{array}$ & 37.831 & 1 & $.000^{* * *}$ \\
\hline $\begin{array}{l}\text { Area of Residence } \\
\text { Rural } \\
\text { Urban }\end{array}$ & $\begin{array}{l}49 \\
51\end{array}$ & $\begin{array}{l}46 \\
54\end{array}$ & .180 & 1 & .777 \\
\hline $\begin{array}{l}\text { Occupation } \\
\text { Unemployed } \\
\text { Employed }\end{array}$ & $\begin{array}{l}88 \\
12\end{array}$ & $\begin{array}{l}80 \\
20\end{array}$ & 2.318 & 1 & .123. \\
\hline $\begin{array}{l}\text { Family Income } \\
\text { (Monthly in Rs.) } \\
0-2000 \\
2001-5000 \\
\quad>5000\end{array}$ & $\begin{array}{l}28 \\
35 \\
37\end{array}$ & $\begin{array}{l}25 \\
39 \\
36\end{array}$ & .400 & 2 & .819 \\
\hline $\begin{array}{l}\text { Age of onset } \\
\text { (in years) }\end{array}$ & $12.48 \pm 8.51$ & $27.82 \pm 11.67$ & -10.623 & 198 & $000^{* * *}$ \\
\hline $\begin{array}{l}\text { Duration of Illness } \\
\text { (in months) }\end{array}$ & $86.70 \pm 80.33$ & $67.23 \pm 69.10$ & 1.837 & 198 & $.068^{\#}$ \\
\hline $\begin{array}{l}\text { Duration of treatment } \\
\text { (in months) }\end{array}$ & $44.45 \pm 57.68$ & $63.84 \pm 66.44$ & -2.204 & 198 & $.029^{*}$ \\
\hline
\end{tabular}

$* \mathrm{p}<.05 * * * \mathrm{p}<.001$ level (2-tailed). \# trend

\section{CAREGIVERS' SOCIO-DEMOGRAPHIC CHARACTERISTICS}

In comparison of socio-demographic and clinical variables of persons with mental illness and epilepsy (Table 1), the age, education, religion, marital status, age of onset $(\mathrm{p}<.001$ level) and duration of treatment
( $\mathrm{p}<.05$ level) emerged as statistically significant. Persons with epilepsy are much younger (19.89 $\pm 10.66)$ than persons with mental illness (34.66 \pm $11.87)$ and their age of onset of illness is also early 


\section{Stigma Experienced by Primary Care Givers : A Comparative Study}

$(12.48 \pm 8.51$ than $27.82 \pm 11.67)$. So it is obvious that duration of illness is more in persons with epilepsy than persons with mental illness but surprisingly duration of treatment is more in persons with mental illness than persons with epilepsy which indicates that their treatment started very late. Persons with epilepsy are having less years of education which could be because of their illness which has started at early age so that they can't study. Young onset and long duration of illness could be also attributed as a reason for less number of married persons with epilepsy in comparison with persons with mental illness. Hindus in our sample seemed to have higher number of persons with epilepsy in comparison to persons with mental illness.

\section{Table 2. Socio-demographic Characteristics of the Care Givers}

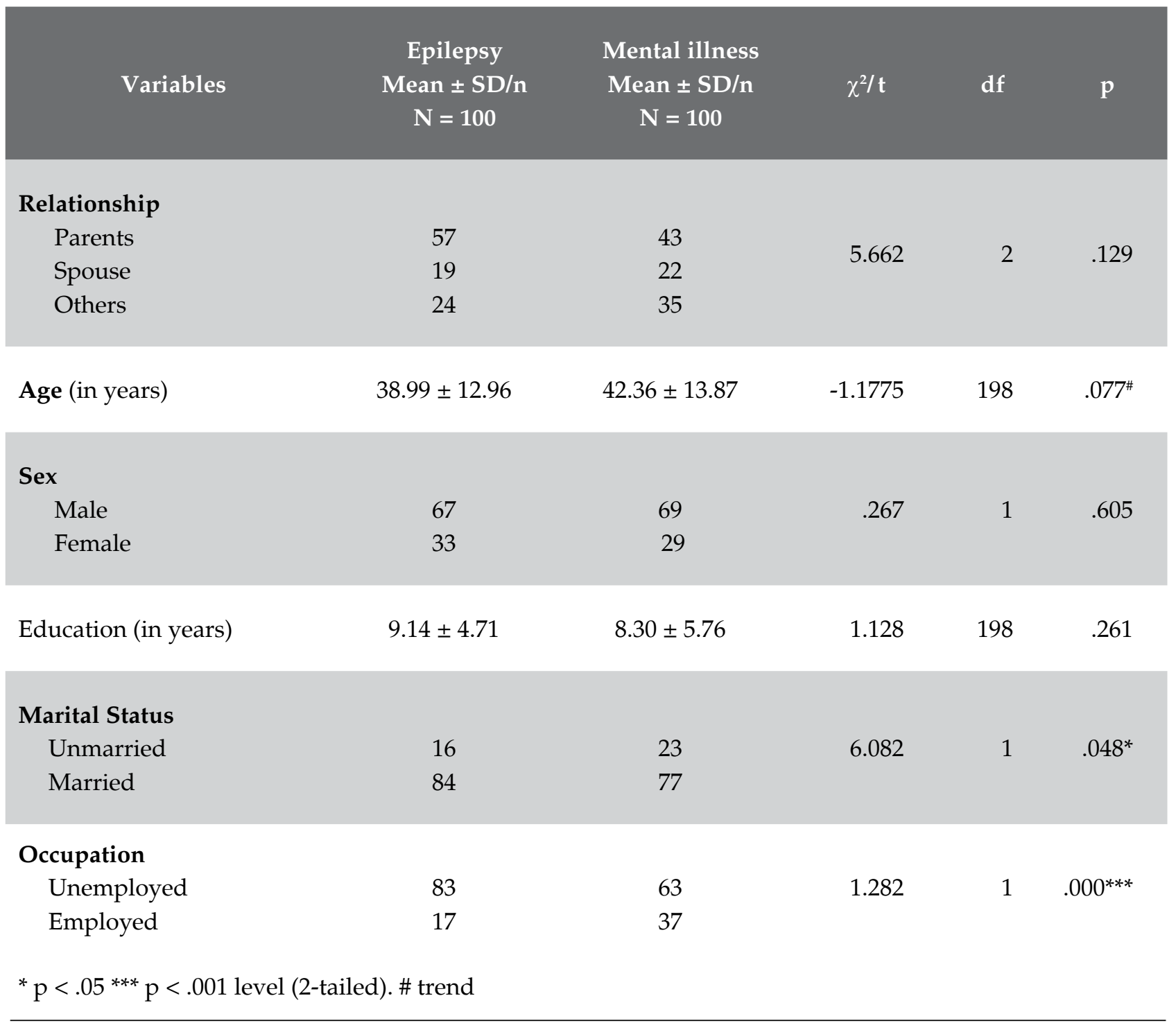

In group comparison of socio-demographic profile of primary care givers of the persons with epilepsy and mental illness (Table 2$)$, marriage $(p<.05$ level) and occupation $(\mathrm{p}<.001$ level) emerged as statistically significant. More number of care givers of persons with epilepsy were married and unemployed than 
care givers of persons to mental illness. Although not statistically significant but it was found that age of care givers of persons with epilepsy tended to be younger than care givers of persons to mental illness.

\section{COMPARISON OF STIGMA EXPERIENCED BY THE PRIMARY CARE GIVERS}

Table 3. Group Comparison of Stigma

\begin{tabular}{|c|c|c|c|c|c|c|}
\hline \multicolumn{7}{|c|}{ Mean $\pm \mathrm{SD} / \mathrm{n}(\mathrm{N}=100)$} \\
\hline Stigma items & & Epilepsy & Mental Illness & $\chi^{2} / \mathbf{t}$ & df & $\mathbf{p}$ \\
\hline $\begin{array}{l}\text { Neighbours would treat } \\
\text { differently }\end{array}$ & $\begin{array}{l}\text { Not at all } \\
\text { Sometime } \\
\text { Often } \\
\text { A lot }\end{array}$ & $\begin{array}{c}48 \\
33 \\
16 \\
3\end{array}$ & $\begin{array}{l}15 \\
40 \\
15 \\
30\end{array}$ & 40.080 & 3 & $.000^{* * *}$ \\
\hline Spend time worrying & $\begin{array}{l}\text { Not at all } \\
\text { Sometime } \\
\text { Often } \\
\text { A lot }\end{array}$ & $\begin{array}{l}53 \\
27 \\
17 \\
03\end{array}$ & $\begin{array}{l}07 \\
50 \\
14 \\
29\end{array}$ & 63.552 & 3 & $.000^{* * *}$ \\
\hline Need to hide fact & $\begin{array}{l}\text { Not at all } \\
\text { Sometime } \\
\text { Often } \\
\text { A lot }\end{array}$ & $\begin{array}{c}55 \\
26 \\
15 \\
4\end{array}$ & $\begin{array}{l}04 \\
38 \\
13 \\
45\end{array}$ & 80.784 & 3 & $.000^{* * *}$ \\
\hline $\begin{array}{l}\text { Helped other people to } \\
\text { understand }\end{array}$ & $\begin{array}{l}\text { Not at all } \\
\text { Sometime } \\
\text { Often } \\
\text { A lot }\end{array}$ & $\begin{array}{l}51 \\
37 \\
10 \\
02\end{array}$ & $\begin{array}{l}37 \\
17 \\
29 \\
17\end{array}$ & 30.733 & 3 & $.000^{* * *}$ \\
\hline Effort to keep as secret & $\begin{array}{l}\text { Not at all } \\
\text { Sometime } \\
\text { Often } \\
\text { A lot }\end{array}$ & $\begin{array}{l}54 \\
13 \\
29 \\
04\end{array}$ & $\begin{array}{l}00 \\
15 \\
28 \\
57\end{array}$ & 1.028 & 3 & $.000^{* * *}$ \\
\hline $\begin{array}{l}\text { Worry that neighbors would } \\
\text { avoid }\end{array}$ & $\begin{array}{l}\text { Not at all } \\
\text { Sometime } \\
\text { Often } \\
\text { A lot }\end{array}$ & $\begin{array}{l}60 \\
18 \\
18 \\
04\end{array}$ & $\begin{array}{l}04 \\
21 \\
21 \\
54\end{array}$ & 92.565 & 3 & $.000^{* * *}$ \\
\hline $\begin{array}{l}\text { Explaining to others that } \\
\text { he/she is not crazy }\end{array}$ & $\begin{array}{l}\text { Not at all } \\
\text { Sometime } \\
\text { Often } \\
\text { A lot }\end{array}$ & $\begin{array}{l}64 \\
25 \\
11 \\
00\end{array}$ & $\begin{array}{l}59 \\
06 \\
27 \\
08\end{array}$ & 26.585 & 3 & $.000^{* * *}$ \\
\hline $\begin{array}{l}\text { Worry that you would be } \\
\text { blamed }\end{array}$ & $\begin{array}{l}\text { Not at all } \\
\text { Sometime } \\
\text { Often } \\
\text { A lot }\end{array}$ & $\begin{array}{l}66 \\
19 \\
14 \\
01\end{array}$ & $\begin{array}{l}30 \\
22 \\
21 \\
27\end{array}$ & 39.262 & 3 & $.000^{* * *}$ \\
\hline
\end{tabular}




\section{Stigma Experienced by Primary Care Givers : A Comparative Study}

Table 3. Group Comparison of Stigma

\begin{tabular}{|c|c|c|c|c|c|c|}
\hline & & Mean \pm SD $/$ & $\mathrm{J}=100)$ & & & \\
\hline Stigma items & & Epilepsy & Mental Illness & $\chi^{2} / t$ & df & $\mathbf{p}$ \\
\hline Worried about taking & Not at all & 58 & 30 & & & \\
\hline him/her & Sometime & 27 & 22 & & & \\
\hline & Often & 13 & 21 & 74.832 & 3 & t. \\
\hline & A lot & 02 & 27 & & & \\
\hline Ashamed / Embarrassed & Not at all & 54 & 13 & & & \\
\hline about it & Sometime & 26 & 57 & & & \\
\hline & Often & 16 & 21 & 39.267 & 3 & $.000^{* * *}$ \\
\hline & A lot & 04 & 09 & & & \\
\hline Sought out families with a & Not at all & 65 & 00 & & & \\
\hline person with epilepsy/mental & Sometime & 27 & 00 & 1705 & 2 & $00 \Omega * * *$ \\
\hline illness & Often & 07 & 76 & & & \\
\hline & A lot & 01 & 24 & & & \\
\hline Felt grief or depression & Not at all & 11 & 00 & & & \\
\hline & Sometime & 21 & 00 & & 3 & $000^{* * *}$ \\
\hline & Often & 25 & 04 & 67.416 & & \\
\hline & A lot & 43 & 96 & & & \\
\hline Felt it might be your fault & Not at all & 72 & 28 & & & \\
\hline & Sometime & 21 & 38 & 18788 & 3 & $0 \cap 0 * * *$ \\
\hline & Often & 07 & 10 & 40.100 & 0 & \\
\hline & A lot & 00 & 24 & & & \\
\hline Total Score in Stigma Items & & $10.14 \pm 6.11$ & $25.25 \pm 4.90$ & -19.30 & 198 & $.000^{* * *}$ \\
\hline ** $\mathrm{p}<.001$ level (2-tailed). & & & & & & \\
\hline
\end{tabular}

Comparison of total mean score in stigma item of both groups reveals that primary care givers of epilepsy (Table 3) group scored $10.14 \pm 6.11$ whereas care givers of mental illness group scored $25.25 \pm 4.90$. It means primary care givers of persons with mental illness were having much stigma than primary care givers of persons with epilepsy. Significant group difference was found between these two groups in all stigma items which indicates difference in nature of stigma experienced by them.

If we consider the positive response in stigma items it is very evident that, a feeling of grief or depression because of the illness (mental illness or epilepsy) in the PCG was highest one in stigma items, seen among $100 \%$ and $89 \%$ of the care givers respectively. The other issue which was highly disturbing to the care givers was the marriage of their ward $(56 \%$ and $100 \%$ in PCG of persons with mental illness and epilepsy respectively). Effort to keep (illness) secret was the concern of all PCG of persons with mental illness whereas only 45\% PCG of persons with epilepsy had this concern. Sought out families with a person with epilepsy (98\%), fears that need to hide fact $(96 \%)$, worried about taking him/her out $(96 \%)$, 


\section{Stigma Experienced by Primary Care Givers : A Comparative Study}

worry that neighbors would avoid (96\%) was the concern of most of the PCG of persons with mental illness whereas majority of the PCG of persons with epilepsy having the fear that neighbours would treat differently (52\%). Most (92\%) of the PCG of persons with mental illness spend time worrying whereas only $47 \%$ PCG of persons with epilepsy having the same. Again, large majority of the PCG of persons with mental illness felt ashamed / embarrassed about it $(87 \%)$, neighbours would treat differently $(83 \%)$ and it might be their fault (72\%) in comparison to their counterpart in the same domains respectively ( $46 \%, 40 \%$ and $28 \%$ ). Majority of the PCG of persons with mental illness were worrying that they would be blamed $(70 \%)$ and $63 \%$ helped other people to understand about the mental illness in comparison to their counterpart in the same domains respectively (34\% and $49 \%$ ).

\section{COMPARISON OF CAUSAL ATTRIBUTION BY THE PRIMARY CARE GIVERS}

\section{Table 4. Causal Attribution by Primary Care Givers}

\begin{tabular}{|c|c|c|c|c|}
\hline Attribution / Causes & $\begin{array}{c}\text { Epilepsy } \\
\text { Mean } \pm \text { SD } \\
\mathbf{N}=100\end{array}$ & $\begin{array}{l}\text { Mental illness } \\
\text { Mean } \pm \text { SD } \\
\mathbf{N}=\mathbf{1 0 0}\end{array}$ & $\stackrel{t}{t}$ & $\mathbf{p}$ \\
\hline Brain injury & $.59 \pm .49$ & $.54 \pm .50$ & .710 & .478 \\
\hline Bereavement & $37 \pm .48$ & $92 \pm .27$ & -9.882 & $.000^{* * *}$ \\
\hline Childhood experience & $.31 \pm .46$ & $.55 \pm .50$ & -3.516 & $.001^{* * *}$ \\
\hline Influence of Depression/Unhappiness & $.40 \pm .49$ & $.88 \pm .33$ & -8.124 & $.000^{* * *}$ \\
\hline Influence of Social Environment & $.32 \pm .47$ & $.83 \pm .38$ & -8.473 & $.000^{* * *}$ \\
\hline Financial worries & $.31 \pm .46$ & $.84 \pm .37$ & -8.935 & $.000^{* * *}$ \\
\hline Homelessness & $.17 \pm .38$ & $.51 \pm .50$ & -5.244 & $.000^{* * *}$ \\
\hline Inherited from parents & $.52 \pm .50$ & $.74 \pm .44$ & -3.322 & $.001^{* * *}$ \\
\hline Insecurity & $.26 \pm .44$ & $.72 \pm .49$ & -7.222 & $.000^{* * *}$ \\
\hline Jealousy & $.14 \pm .35$ & $.40 \pm .49$ & -4.172 & $.000^{* * *}$ \\
\hline Stress (unspecified) & $.46 \pm .50$ & $.90 \pm .30$ & -4.107 & $.000^{* * *}$ \\
\hline Stress home & $.46 \pm .50$ & $.86 \pm .35$ & -7.457 & $.000^{* * *}$ \\
\hline Stress at work & $.46 \pm .50$ & $.80 \pm .40$ & -6.384 & $.000^{* * *}$ \\
\hline Possessed by sprits & $.32 \pm .47$ & $.63 \pm .49$ & -5.235 & $.000^{* * *}$ \\
\hline Effect of the moon & $.32 \pm .47$ & $.25 \pm .44$ & 1.023 & .308 \\
\hline Difficulties in intimate relationship & $.21 \pm .41$ & $.76 \pm .43$ & -9.019 & $.000^{* * *}$ \\
\hline Character or life style & $.27 \pm .45$ & $.36 \pm .48$ & -1.377 & .170 \\
\hline Age & $.06 \pm .24$ & $.64 \pm .48$ & -10.608 & $.000^{* * *}$ \\
\hline Substance abuse & $.43 \pm .50$ & $.70 \pm .46$ & -3.932 & $.000^{* * *}$ \\
\hline Faulty biological function & $.32 \pm .47$ & $.46 \pm .50$ & -2.016 & $.045^{*}$ \\
\hline Faulty nutrition habit & $.28 \pm .45$ & $.54 \pm .50$ & -3.750 & $.000^{* * *}$ \\
\hline Specific precipitating events & $.05 \pm .22$ & $.87 \pm .34$ & -19.934 & $.000^{* * *}$ \\
\hline No cause it just happened & $05 \pm .22$ & $.27 \pm .45$ & -4.458 & $.000^{* * *}$ \\
\hline Don't know & $.03 \pm .17$ & $.23 \pm .42$ & -4.363 & $.000^{* * *}$ \\
\hline Other cause & $.00 \pm 00$ & $.00 \pm 00$ & - & - \\
\hline
\end{tabular}

${ }^{*} \mathrm{p}<.05^{* * *} \mathrm{p}<.001$ level (2-tailed). 


\section{Stigma Experienced by Primary Care Givers : A Comparative Study}

Group comparison between primary care givers of the persons with mental illness and epilepsy (Table 4) in causal attribution items reveal significant difference in almost all items except brain injury, effect of the moon and character or life style.

Table 5. Rank order of Causal attribution items

\begin{tabular}{|c|c|c|}
\hline \multirow{2}{*}{ Causes of Psychosis/ Epilepsy } & \multicolumn{2}{|c|}{ Causal Attribution } \\
\hline & Psychosis & Epilepsy \\
\hline Bereavement & 92 & 37 \\
\hline Influence of Depression/Unhappiness & 88 & 40 \\
\hline Financial worries & 84 & 31 \\
\hline Influence of Social Environment & 83 & 32 \\
\hline Stress (unspecified) & 82 & 46 \\
\hline Specific precipitating events & 79 & 5 \\
\hline Stress home & 78 & 46 \\
\hline Stress at work & 73 & 46 \\
\hline Difficulties in intimate relationship & 69 & 21 \\
\hline Inherited from parents & 68 & 52 \\
\hline Insecurity & 66 & 26 \\
\hline Substance abuse & 64 & 43 \\
\hline Age & 58 & 6 \\
\hline Possessed by sprits & 57 & 32 \\
\hline Childhood experience & 55 & 31 \\
\hline Brain injury & 54 & 59 \\
\hline Faulty nutrition habit & 49 & 28 \\
\hline Homelessness & 46 & 17 \\
\hline Faulty biological function & 42 & 32 \\
\hline Jealousy & 36 & 14 \\
\hline Character or life style & 33 & 27 \\
\hline No cause it just happened & 25 & 5 \\
\hline Effect of the moon & 23 & 32 \\
\hline Don't know & 21 & 3 \\
\hline Other cause & 1 & 0 \\
\hline
\end{tabular}




\section{Stigma Experienced by Primary Care Givers : A Comparative Study}

If we see the rank order of attribution for mental illness and epilepsy (Table 5), almost all (92\%) PCG of persons with mental illness had attributed bereavement as a cause for mental illness whereas the largest number of PCG of persons with epilepsy had attributed brain injury $(59 \%)$ as cause of epilepsy in their family member. Second most frequent attribution for mental illness was influence of depression/unhappiness (84\%) and inherited from parents (52\%) was for epilepsy. The common causes for mental illness were : influence of social environment (83\%), unspecified stress $(82 \%)$, specific precipitating events $(79 \%)$, stress at home $(78 \%)$, stress at work $(73 \%)$, difficulties in intimate relationship $(69 \%)$, inherited from parents $(68 \%)$, insecurity (66\%), substance abuse $(64 \%)$, age (58\%), possessed by sprits (57\%), childhood experience $(55 \%)$ and brain injury (54\%). Whereas for epilepsy, stress unspecified or from either source home or work $(46 \%)$ were attributed by the PCG. Substance abuse $(43 \%)$, influence of depression/unhappiness $(40 \%)$, bereavement $(37 \%)$, and influence of social environment, faulty biological function, possessed by sprits, effect of the moon is equally (32\%) attributed causes. Other causes are less preferred by PCG.

\section{CONCLUSION AND IMPLICATION}

It can be concluded from this study that the primary caregivers of persons with mental illness experienced a greater degree of stigma than the primary caregivers of epilepsy, which may have detrimental effects in the recovery and reintegration of persons with mental illness in the community. Differences in causal attribution between both groups indicates that causative factors about mental illness differ from epilepsy, which have important implication in psycho-educational programs of intervention to dispel stigma. It was also observed that primary caregivers of epilepsy also experienced stigma though it was lesser in comparison of what persons with mental illness experienced.

\section{REFERENCE}

Ablon J. The nature of stigma and medical conditions. Epilepsy Behav 2002; 3 (6s2) : 2-9.

American Psychiatric Association. Diagnostic and Statistical Manual of Mental Disorders. 4th ed. Text rev. Washington, DC : American Psychiatric Association; 2000.

Angermeyer MC, Matschinger H. Lay beliefs about schizophrenic disorder: the result of a population study in Germany. Acta Psychiatry Scand 1994; 89 : 39-45.

Corrigan PW, Penn DL. Lessons from social Psychology on discrediting psychiatric stigma. Am Psycho 1999; 54 : 765-6.

Demyttenaere K, Bruffaerts R, Posada-Villa J, Gasquet I, Kovess V, Lepine JP, et al. Prevalence, severity and unmet need for treatment of mental disorders in the World Health Organisation World Mental Health Surveys. JAMA 2004; 291 : 2581-90.

Ganguli HC. Epidemiological findings on prevalence of mental disorders in India. Indian J Psychiatry 2000; 42 : 14-20.

Goffman E. Stigma : notes on the management of spoiled identity. New York: Pelican Books : 1963.

Hebl MR \& Mannix LM. The weight of obesity in evaluating others : A mere proximity effect. Pers Soc Psychol Bull; $2003 ; 29,28-38$.

International League against Epilepsy. Proposal for revised clinical and electroencephalographic classification of epileptic seizures. Epilepsia 1981; 22 : 489-501.

Mario R, Mendez. Neuopsuchiatric Asoects of Epilepsy. In : Kaplan RS, Sadock VA, (eds). Comprehensive Textbook of Psychiatry. Philadelphia: Lippincott William and Wilkins $2000: 375-85$.

Neuberg SL, Smith DM, Hoffman JC, \& Russell FJ. When we observe stigmatized and "normal" individuals interacting : Stigma by association. Pers Soc Psychol Bull; 1994; 20, 196-209.

Opala J, Boillot F. leprosy among the limba: illness and healing in the contex of world view. Soc Sci Med 1996; 42: 3-19.

Pandey S. Behavioural Management in Epilepsy. An unpublished dissertation, Ranchi : Central Institute of Psychiatry, 2001.

Pasternak J. An analysis of social perceptions of epilepsy : increasing rationalization as seen through the theories of Comte and Weber. Soc Sci Med, 1981; 15E, 3.

Phelan JC, Link BG, Stueve A. Pescosolido B. Public conceptions of mental illness in 1950 and 1960: What is mental illness and it to be feared. J Health Soc Behav 2000; 41 : 188-207.

Ray BK, Bhattacharya S, Kundu TN, Saha SP, Das SK. Epidemiology of epilepsy-India perspective. J Ind Med Assoc 2002; 100 (5) : 322-26. 


\section{Stigma Experienced by Primary Care Givers : A Comparative Study}

Reddy MV, Chandrasekar CR. Prevalence of mental and behavioral disorders in India: A meta-analysis. Indian J Psychiatry 1998; 40: 149-57.

Sahu KK, Pillai RR, Hazra S, Verma AN. Stigma experienced by primary care givers of persons with Epilepsy. National Journal of Professional Social Work. 2009-10 (1 \& 2) 17-33.

Sartorius N, Gulbinat W., Harrison G, Laska E, Siegel C. Longterm follow-up of schizophrenia in 16 countries. Soc Psych Psych Epid, 1996; 31, 249-58.

Shamsundar C, Sriram TG, Muralirey SG. Shamughaml. Validity of a short versin of GHQ. Indian J Psychiatry, 198628 (3), 217-19.

Suman DC. A study of psycho-social factors in married people with epilepsy. An unpublished dissertation, Ranchi : Central Institute of Psychiatry, 2000.
Thara R, \& Srinivasan TN. How stigmatizing is schizophrenia in India. Int J Soc Psychiatr, 2000; 46(2), 135-41.

Weiss MG, \& Ramakrishna J. Stigma interventions and research for international health. Lancet 2006, 367(9509), 536 - 38.

Weiss MG, Jadhav S, Raguram R, Vounatsou P, Littlewood R. Psychiatric stigma across cultures : Local validation in Bangalore and London. Anthropol Quart, 2001; 8, 71-87.

World Health Organization. World Health Report 2001-Mental Health: A new understanding. New hope. Geneva : World Health Organization; 2001.

World Health Organization. ICD-10 Clinical Descriptions and Diagnostic Guidelines. Geneva : World Health Organization 1992. 